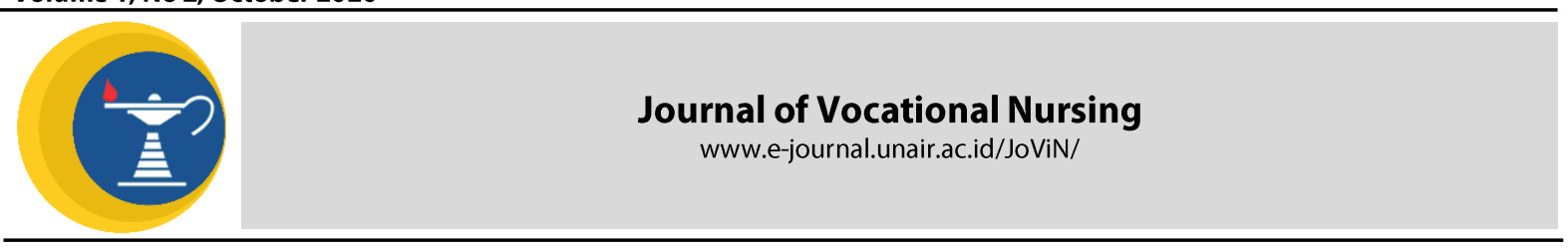

\title{
BODY IMAGE IN DIABETES MELITUS PATIENTS WITH ULCUS DIABETIC IN GRESIK
}

Hafna Ilmy Muhalla

Research Report

DIII Nursing Study Program, Departement of Health, Faculty of Vocational Studies, Universitas Airlangga

\section{ABSTRACT}

Introduction: Indonesia is ranked 4th in the world for the number of diabetics according to WHO, and most of diabetics experience complications, one of which is ulcer diabetikum. This can be a trigger for the emergence of body image disorders from diabetics, so researchers need to know the picture of ulcus sufferers'body image to later be mapped and make it easier in subsequent handling. The research objective is to describe the image of body image in patients with diabetes mellitus with ulcus complications. Physical changes in the body can affect body image and self-esteem Methods: Design of this study used a descriptive research design, the population in this study were all patients who have diabetes mellitus with ulcus diabeticum in Ibnu Sina Hospital Gresik regency with a sample of 20 respondents, samples were taken by using purposive sampling technique. Data collection using questionnaires with 15 multiple choices question. Furthermore, the data were analyzed with coding, scoring, tabulating presentatif, and described. Results: The results showed a total of 20 respondents obtained ii'om 5 respondents (25\%) have a good body image, 7 respondents (35\%) had a poor body image and 8 respondents (40\%) who did not have a good body image. Conclusion: Based on the results of this study indicate that in patients with diabetes mellitus who are already experiencing complications of ulcus diabetic almost half of respondents do not have a good body image, and a small proportion of respondents have a good body image. This is due to several factors, namely the respondents admitted that the wounds on his legs is a sign of personal failure on him therefore to improve body image and the changing assessment of the physical condition and provide social support.

\section{ARTICLE INFO}

Recived 19 October 2020

Accepted 25 October 2020

Online 29 October 2020

*Correspondence:

Hafna Ilmy Muhalla

*Email:

hafnailmy@gmail.com

\section{Keywords:}

Diabetes Mellitus, Ulcus Diabetic Body Image

\section{INTRODUCTION}

Diabetes mellitus (DM) is a disorder of carbohydrate, fat and protein metabolism that is associated with relative or absolute deficiency of insulin secretion characterized by chronic hyperglycemia caused by environmental and hereditary factors (Roza, 2015).

According to Diabetes Atlas 2009, Indonesia is ranked 9th most in the world of people with DM, with the rate of occurrence of DM in Indonesia as it is today, in 2012 Indonesia ranks seventh in the world most people with DM (Triyanisya, 2013).

Diabetes mellitus (DM) is a noncommunicable disease that will increase in number and will be the biggest cause of morbidity and mortality. Diabetes is a serious disease and should be given attention because diabetes can cause complications that affect the entire body (Smeltzer, Bare, Hinkle \& Cheever, 2008).

Ulcus diabetic is a complication of chronic diabetes, ulcus diabetic is a decay that occurs due to diabetes that occurs throughout the body. The location of the initial decay usually starts from the foot then spreads throughout the body. Ganggren is very feared by diabetes mellitus sufferers because they need extra care (Soeryoko, 2011).

Diabetic feet that are not properly treated will easily experience injury, and quickly develop into gangrene ulcers if not treated properly, this results in disruption of body image (body image) changes in perception about the body caused by changes in the size of shapes, structures, functions, limitations, meanings and objects that are often in contact with the body (Kusuma, 2010).

The prevalence of diabetes mellitus in the world has reached the number of outbreaks or 
epidemics. WHO estimates that in developing countries in 2025 there will be $80 \%$ of new cases. Currently, Diabetes Mellitus at the world level is estimated to be more than 230 million, almost reaching the proportion of $6 \%$ of the adult population (Padila, 2012)

Diabetes is a serious threat for people with diabetes mellitus, because the number of people with diabetes mellitus in Indonesia has increased from year to year. It can experience some health problems, is a stressor and can affect self-concept. Physical changes in the body can affect body image and self-esteem (Poter Perry, 2009).

Diabetic ulcer complications in DM patients can have an effect on their body image. Body image is a collection of individual attitudes that are conscious and unaware of the body, including perceptions of the past and present, as well as feelings about the structure, shape and function of the body (Keliat, Helena \& Farida, 2011).

In complications of diabetes mellitus there are acute complications and chronic complications. acute complications can occur in coma ketoacidosis and infection, chronic complications can occur in all blood vessels throughout the body (diabetic angiopathy), and have a high risk of coronary heart disease (PIK), cerebral vascular disease 2 times larger, 50 times easier suffering from illus / gangrene, 7 times easier to suffer from terminal kidney failure and 25 times more likely to experience blindness due to retinal damage (FKUI, 2009).

Health problems due to complications of diabetes mellitus can be eye disorders (retinopathy), kidney disorders (nephropathy), blood vessel disorders (vasculopathy) and abnormalities in the legs (diabetic foot / diabetic foot) (Syarif, 2013).

The most frequent complication is diabetic foot. Pathological changes in the lower limbs can be nerve abnormalities (neuropathy), structural changes, skin bumps (callus), skin and nail changes, foot injuries, infections and blood vessel abnormalities. If not handled properly, it will become gangrene and sometimes it must be amputated (LeMone \& Burke, 2008).

Problems with diabetic gangren clients are indeed very complex, in addition to physical, psychological problems are also disturbed. One of the problems that might arise is self-concept disorder. Often the client feels embarrassed because of the unpleasant odor that comes from the wound he has, the form of the scary wound and makes them tend to close themselves and cannot carry out their role perfectly in the community (Nuridayanti, 2018).

According to Chaplin (2010) that body image or body image or body concenpt is a person's idea about the appearance of his body in front of other people.

In clients who are intensively treated at the hospital, changes in body image are very likely to occur, stressors of changes in body shape, invasive actions such as surgery, injection of infusion area. Changes in structure together with changes in body shape accompanied by the installation of tools in the body are limited movement, eating, activities. The meaning of objects is often contact, appearance changes, installation of tools on the client's body (infusion, respirator, injection, examination of vital signs and others), (Tjokroprawiro, 2011).

\section{MATERIALS AND METHODS}

The design in this study is descriptive or illustrates nursing research problems that occur in cases of an illness based on the distribution of place, time, age, gender, socioeconomic, occupation, and marital status, way of life and others. The population in this study were all patients with diabetes mellitus with diabetic ulcers. The sample in this study was determined using purposive sampling with a total of 20 respondents and fulfilled the following inclusion criteria: patients with diabetic ulcers who were hospitalized and had stage IV diabetic ulcers

\section{RESULTS}

Table 1 Distribution of Respondents by Gender

\begin{tabular}{ccccc}
\hline No & Gender & Total & Percentage \\
\hline 1 & Male & 10 & 50 \\
2 & & Female & 10 & 50 \\
\hline & Total & & 20 & 100 \\
\hline
\end{tabular}

shows that the respondent's gender is evenly divided, $50 \%$ male and $50 \%$ female. 
Table 2 Distribution of Respondents Based on Length of Diabetes Mellitus

\begin{tabular}{cccc}
\hline No & $\begin{array}{c}\text { Length of Diabetes Mellitus } \\
\text { (Years) }\end{array}$ & Total & Percentage \\
\hline 1 & 1 & 3 & 15 \\
2 & 5 & 9 & 45 \\
3 & 10 & 1 & 5 \\
4 & 15 & 2 & 10 \\
5 & $>15$ & 5 & 25 \\
\hline & Total & 20 & 100 \\
\hline
\end{tabular}

shows that almost half of the respondents suffered from diabetes mellitus 5 years ago (45\%) and a small proportion of respondents had diabetes mellitus 10 years ago $(5 \%)$.

Table 3 Distribution of Respondents by Age

\begin{tabular}{cccc}
\hline No & Body Image & Total & Percentage \\
\hline 1 & Good & 5 & 25 \\
2 & Not so Good & 7 & 35 \\
3 & Not Good & 8 & 40 \\
\hline & Total & 20 & 100
\end{tabular}

shows that almost half of the respondents possessed a bad body image (40\%) and a small number had a good body image (25\%).

\section{DISCUSSION}

From the results of data collection through questionnaire sheets in the inpatient room of Ibnu Sina General Hospital, Gresik Regency, it was obtained from a total of 20 respondents 5 respondents (25\%) had good body image, 7 respondents $(35 \%)$ had poor body image and 8 respondents (40\%) had body image is not good.

In this study the majority of respondents obtained a body image that was not good on him, this could occur because in the general data found in patients with diabetes mellitus who have had gangrenous complications have experienced a high amount of sensory decline in the foot. In respondents who experienced a bad body image, 31183 was caused by several factors, namely the respondent felt that the presence of a wound on his leg was a sign of personal failure, felt ashamed of the changes in his body's current condition of 14 respondents and thought he had no for the high spirits of life as many as 11 respondents.

The above is in accordance with the theory according to Nizam (2014) the changes that can occur in the body image are: Changes in body size such as for someone who has a low body weight due to the illness it affects greatly body image. Changes in body shape, for example in invasive actions such as surgery, changes in structure are the same as changes in body shape, namely the action with the installation of tools in the body Changes in functions, for example in various diseases that can change the body system, for example in patients with diabetes mellitus with the presence of gangrenous wounds can also affect the image of one's body image.

In respondents who experience a good body image it can occur because of the correct perception of the individual form, the individual sees his body according to the actual conditions. Based on the general data collection, the patient also said that to improve his body image, namely by doing regular exercise activities every morning, and individuals appreciating the body / body that is experienced at this time, individuals also understand that a person's physical appearance only plays a small role in showing their character and the value of someone. The individual feels proud and accepts his current body shape and considers that he does not have a sign of personal failure on him. Individuals feel confident and comfortable with their body condition. Besides that the results obtained from the study according to general data respondents also underwent regular control every month, taking medication regularly, and food diit according to the rules of the doctor.

The above according to Potter \& Perry (2009) factors that influence body image, namely: Stressors, personal views, cognitive growth and physical development, attitudes and social culture. Stressor is a change in the appearance, structure, or function of body parts that will require changes in body image. on changes in the appearance of the body, such as amputations or changes in the appearance of the face is a stressor that very clearly affects body image (Body Image). 
Also found in respondents who have a body image that is not good according to the results of research through the questionnaire sheet also occurs because individuals also feel disturbed after knowing there is a change in form that is gangrenous complications but individuals still have a high spirit of life and family still give enthusiasm for his recovery and consider this is not a curse from God.

The above is in accordance with the theory according to Perry \& Potter (2009) efforts to improve Body Image (Body Image), namely: changing people's judgments and satisfaction with their current physical, emotional, and social functions, making effective coping strategies, providing social support.

Anxiety greatly affects the psychological health of a person suffering from diabetic ulcer, anxiety increases because of worries about wounds / ulcers / ulcers that will not heal, feelings of loss of motivation to rise and even to wash and dress even, loss of freedom, frustrated because it becomes a burden on the family, and fear of amputation (Bradbury \& Price, 2011).

For someone who has a change in appearance and function, the body tends to have a negative body image. Research conducted by Sitorus (2011) on the description of the body image of post-amputation patients showed that more than half of the respondents had a negative body image.

The same thing happens to a woman who has breast cancer. For DM patients, Sofiyana (2011) conducted a study by linking stress with selfconcept in DM patients conducted at Arifin Achmad Hospital. It was found that most DM patients (63.3\% of 30 respondents) had negative body images.

\section{CONCLUSION}

Based on the results of research and discussion about the image of body image in patients with diabetes mellitus with Gangren in RSUD Ibnu Sina Gresik Regency, it can be concluded that almost half of the respondents had a bad body image.

\section{REFERENCES}

Anderson, Elizabet T, (2007). Buku Ajar Keperawatan Komunitas Teori dan Praktik, EGC : Jakarta.

Bradbury, S., \& Price, P. (2011). The Impact of Diabetic Foot Ulcer Pain on Patient Quality of Life. 7(4). Cradiff Univeristy. United Kingdom.

Chaplin, J. P. (2010). Dictionary of psychology. USA: Random House Publishing Group.
Diani, N. (2013). Pengatahuan dan praktik perawatan kaki pada klien diabetes mellitus tipe 2 di Kalimantan selatan. Depok: Universitas Indonesia. Diperoleh tanggal 4 Juli 2014 dari http://lontar.ui.ac.id/file ?file=digital/20334297-T32594-Noo r\%20Diani. Pdf.

FKUI. 2009. Penatalaksanaan Diabetes Mellitus Terpadu. Jakarta : Penerbit FKUI.

Handayani, T. N. (2010). Pengaruh pengelolaan depresi dengan latihan pernafasan yoga (pranayama) terhadap perkembangan proses penyembuhan ulkus diabetic di rumah sakit Pemerintah Aceh. Depok: Universitas Indonesia. Diperoleh pada tanggal 12 Juli 2014 dari http://lontar .ui.ac.id/file?file=di gital/137186-T\%20Tri \%20Nur\%20 Handayani.pdf.

Hastuti, R. T. (2008). Faktor-faktor risiko ulkus diabetika pada penderita diabetes mellitus. Semarang: Universitas Diponogoro. Diperoleh tanggal 11 Juli 2014 dari http://eprints.undip.ac.id/18866/1/Rini_T ri_ Hastuti.pdf.

Keliat, B. A., Helena. N., \& Farida. P. (2011). Manajemen keperawatan psikososial \& kader kesehatan jiwa. (ed.2). Jakarta: EGC.

Kusuma Farida dan hartono 2010. Buku Ajar Keperawatan Jiwa. Jakarta : Salemba Medika.

LeMone, P., \& Burke, K. (2008). Medical Surgical Nursing: Critical Thinking in Client Care. 4th edition. USA: Pearson prentice hall.

Nizam, Wan Khairul, dkk. 2014. Faktor-Faktor yang mempengaruhi Citra Tubuh Pasien Diabetes Melitus yang Mengalami Ulkus Diabetikum. JOM PSIK Vol. 1 No. 2. Oktober 2014.

Nuridayanti, Ani. 2018. Hubundan Kemampuan Intelegensia dan Kecerdasan Emosi dengan Gangguan Konsep Diri pada Klien Gangren Diabetik di Ruang Raflesia RSUD Gambiran Kota Kediri. JuKe Vol. 2 No. 2, Juli - Desember 2018.

Padila 2012. Keperawatan Medikal Bedah. Yogyakarta: Nuha Medika.

Potter \& Perry. 2009. Fundamental Keperawatan. Edisi 7. Jakarta : Salemba Medika.

Potter, A. P. \& Perry, G. A. (2010). Fundamental keperawatan. Jakarta: Salemba Medika.

Purwanti, O. S. (2013). Analisis faktor-faktor risiko terjadi ulkus kaki pada pasien diabetes mellitus di RSUD DR. Moewardi. Depok: Universitas Indonesia. Diperoleh pada tanggal 15 Juli 2014 dari 
http://lontar.ui.ac.id/file?file=digital/203 34094T325400kti\%20Sri\%20Purwanti.pdf.

Roza, Rizky Loviana, dkk. Faktor Risiko Terjadinya Ulkus Diabetikum pada Pasien Diabetes Mellitus yang Dirawat Jalan dan Inap di RSUP Dr. M. Djamil dan RSI Ibnu Sina Padang. Jurnal Kesehatan Andalas 2015.

Sitorus, R. R. (2011) Gambaran Citra Tubuh Pasien Paska Amputasi di Poliklinik Bedah Orthopedi RSUP H. Adam Malik Medan dan RSUD DR. Pirngadi Medan. Medan: Universitas Sumatera Utara. Diperoleh pada tangga 9 Juli 2014 dari http://repo sitory.usu.ac.id/bitstlream/12345689/2 2828/4/Chapter\%20ll.pdf.

Smeltzer, S.C., Bare, B.G., Hinkle, J.L., \& Cheever, K, H. (2008). Textbook of Medical-Surgical Nursing. Eleventh edition. Brunner, \& Suddarth's. Philadhelpia Lippincott Williams \& Wilkins, a Wolter Kluwer bussiness.
Soeryoko. 2011. 25 Tanaman Obat Ampuh Penakluk Diabetes Mellitus. Yogyakarta : CV. Andi Offset.

Sofiyana, L. I. (2011). Hubungan antara stress dengan ctra tubuh pada penderita diabetes melitus. Pekanbaru: UR. (Naskah asli tidak dipublikasikan).

Sudoyo, W.A., Setiyohadi, B., Alwi, I., Simadibrata, M. K., \& Setati, S. (2009). Ilmu penyakit dalam. Jakarta: Interna Publishing.

Syarif, Hilman. Kualitas Hidup Pasien Diabetik di Poliklinik Endokrin RSUDZA, Banda Aceh. Idea Nursing Journal Vol. IV No. 12013.

Taylor, C., Lillis, C., \& Lemone, P (2008). Fundamental of nursing. (5th). Philadelphia: Lippincott Williams \& Wilkins.

Tjokroprawiro. 2011. Panduan Lengkap Pola Makan Untuk Penderita Diabetes. Jakarta : PT. Gramedia Pustaka Utama.

Triyanisya. (2013). Jumlah penyandang diabetes di Indonesia terbanyak ketujuh di dunia. Metrotvnews. Diperoleh tanggal 20 November 2018, dari http://www.metrotv news .com. 